\title{
EFFECT OF NANO-SILVER PARTICLES SUPPLEMENTATION IN DRINKING WATER ON PERFORMANCE AND INTESTINAL MICRO-FLORA POPULATION OF GROWING POULTRY
}

\author{
A.I. El-Faham M.H.S. El-Sanhoury and M.M.E. Mostafa \\ Poultry Production Department, Faculty of Agriculture, Ain Shams University, Cairo, Egypt
}

(Received 3/7/2017, accepted 14/8/2017)

\section{SUMMARY}

$\mathrm{T}$ Three experiments were conducted to investigate the effects of drinking water supplementation with 0,5 and $10 \mathrm{ppm}$ of Nano-silver particles (AgNPs) / liter on performance, carcass characteristics and gut micro-flora population of grower rabbits from 63 to 91day of age, broiler chicks from 1 to 42 day of age and grower Japanese quails from 7 to 42 days of age. Results showed that, different levels of AgNPs in drinking water hadn't any significant effect on body weight, body weight gain (BWG) or feed conversion ratio (FCR) of rabbits. Concerning broiler chicks; the control group performed well compared with supplemented groups. Both BWG and FCR for Japanese quails recorded best values for $10 \mathrm{ppm}$ supplemented group compared with control group. In all tested poultry species, the levels of 5 $\mathrm{ppm}$ and $10 \mathrm{ppm}$ resulted in a reduction in total viable bacteria, pathogenic bacteria representing E Coli and beneficial bacteria representing Lactobacillus of intestinal gut especially for $10 \mathrm{ppm}$ level causing negative effect on performance of grower broiler chicks but less on grower rabbits or Japanese quail, suggesting that, both species may be less sensitive for existence of AgNPs in drinking water, while broiler chicks might be more sensitive. Most of carcass characteristics were not significantly affected by existence or level of drinking water AgNPs supplementation except liver percent of grower quail, which needs to undergo more research works.

Keywords: Nano-Silver particles - drinking water - rabbits-broilers-quails - performance intestinal micro-flora.

\section{INTRODUCTION}

Since of banning the incorporation of antibiotics in poultry and animal feeds as growth promoters by Europian Union in 2006 (WHO,2006) due to those risky side effects on human health, poultry nutritionists dedicated their efforts for finding safe antibiotic alternatives as growth promoters such as probiotics, prebiotics, organic acids and their derivatives, phytobiotics ..... etc..

Nanotechnology is termed on techniques of producing any material including minerals provided their particles size should be ranged between 1 to 100 nanometer. This dimension of nanoparticles for different minerals including silver (nanoparticle silver) if added to animal feed is suitable to pass through the gastrointestinal tract more quickly and efficiently than the common large-sized particles. Due to this specification, Nano minerals possess more desired properties than the common ones; Nano silver (AgNPs) is the most Nano minerals subjected to investigation as growth promoter in poultry diets. Lepianka and Soko (2006) and Hang et al (2014) reported that AgNPs is the best and safely growth promoters would be added to poultry diets due to its positive effects on performance and quantitative and qualitative bacterial population in gastrointestinal tract.

It is noticeable that its effect on poultry species (rabbits, broiler and quails) as feed or water supplementations was conflicted and has no specific trend especially in relation to intestinal microflora or body weight parameter although the tested doses were quantitively close. When AgNPs was tested as broiler diet supplementation, Ahmadi and Kurdestani (2010) reported a non significant effect on body weight, but Ahmadi (2009) and Andi et al. (2011) showed a significant positive effect on broiler performance. While Pineda et al. (2012) showed a non 
significant effect for dietary supplementation with levels of 0,10 and $20 \mathrm{mg} / \mathrm{Kg}$ on broiler performance or intestinal microflora counts. When Ahmadi and Rahimi (2011) added AgNPs to drinking water, they stated a negative effect on chick performance compared to unsupplemented group. However, Kout El kloub et al. (2015) reported that the level of $4 \mathrm{ppm}$ AgNPs/Kg had more significant effect on productive performance than 6,8 and $10 \mathrm{ppm} / \mathrm{Kg}$ of broiler diets. From the little researches those carried on grower quails, and rabbits, Marwa et al. (2012) studied the effect of Nano-silver on reproductive traits of laying quail in drinking water with level of $20 \mathrm{ppm}$. These authors found highly significant effect of the interaction between age at mating and the administration of Nano-silver on live body weight of quail at all growing periods. They attributed that to NAgPs boosting effect on count of beneficial bacteria and suppression effect on pathogenic bacteria of gastrointestinal tract. According to Hang and Tra (2013); AgNPs supplementation in drinking water of rabbits till 40 ppm didn't significantly affect reproductive traits or performance of does or litters. Concerning NAgPs effect on specific microbial population of intestinal tract, results were inconsistent and had unclear trend nevertheless in poultry species, where Burrell et al. (1999) stated that AgNPs have killing effect on broad spectrum of intestinal microflora including beneficial and pathogenic colonies, causing many undesirable effects on nutrient digestibility, absorption and utilization. Also, Grodzik and Sawosz (2006) conceded that AgNPs less than 2nm in diameter can kill bacteria on contact but they didn't recognize the bacterial species. While Sowosz et al. (2007) reported insignificant effect of dietary supplemented with AgNPs on microbial population of intestine gut with $0,5,15$ and $25 \mathrm{mg} /$ liter water, while, Hassanabadi et al. (2012) reported a significant improvement in count of Lactobascilli of intestinal tract related to dietary level of 1.5 and $3 \mathrm{ppm} / \mathrm{kg}$ of AgNPs supplementation compared to unsupplemented group. However, Kout El kloub et al. (2015) reported that, broilers fed different levels of AgNPs $(2,4,6,8$ and $10 \mathrm{ppm} / \mathrm{Kg}$ ) had decreased the number of harmful bacteria represented as E. Coli compared to control and had no effect on Lactobacillus micro-flora .

Based on referred reviews, it is clear that, no obvious trend related to the dietary or drinking water AgNPs supplementation on microbial population of gastrointestinal tract and poultry performance regardless of species. Additionally, grower rabbits didn't attain a sufficient investigation inrelation to AgNPs particularly as drinking water supplementation. Accordingly, this study aimed to investigate the performance and intestinal microflora changes resulted from supplementation of drinking water with AgNPs offered to broiler chicks, grower Japanese quail and grower rabbits.

\section{MATERIALS AND METHODS}

Three experimental trials were carried out using grower rabbits (Exp.1), broiler chicks (Exp.2) and grower Japanese quails (Exp.3) those offered drinking water contained 3 levels of AgNPs (Nano-silver particles). Levels of experimental AgNPs in drinking water were 0 ppm (control group), 5ppm and $10 \mathrm{ppm} /$ liter. Drinking water was offered to rabbits and broiler chicks through overall period by automatic nipples while Japanese quail offered drinking water from 1day old to 14 day old by plastic waters then by automatic nipples from 15 to 42 day old.

\section{Experimental poultry management:}

Exp.1: Forty five mixed sex New Zealand (NZW) rabbits at 63 days of age with an average initial body weight $=1177 \mathrm{~g}$ were randomly assigned to 3 experimental groups of 15 rabbits each for 4wks trial period, Rabbits were offered 3 levels of experimental AgNPs in drinking water as $0 \mathrm{ppm}$ (control group), 5ppm and $10 \mathrm{ppm} /$ liter. Rabbits were kept individually in 3 one-side batteries in a closed system house using controlled system that kept relative humidity around 65 to $70 \%$ and 22 to $28{ }^{\circ} \mathrm{C}$ temperature. Each battery contained 1 stair with 5 cages each (each one was $50 \times 50 \times 35 \mathrm{~cm}$ for length, width and hight, respectively). Rabbits were subjected to 12 to 14 daily light programs through experimental period and offered ad libitum grower diet as described in Table (1) using individual metallic feeders. 
Table (1). Feed ingredients and calculated chemical composition of broiler chick diets (135d), Japanese quail diet (7-42d) and rabbit diet (63 to 91d) of age.

\begin{tabular}{|c|c|c|c|c|c|}
\hline \multirow[t]{2}{*}{ Ingredient } & \multicolumn{3}{|c|}{ Broiler chicks } & \multirow{2}{*}{$\begin{array}{c}\text { Jap. Quail } \\
(7-42 d)\end{array}$} & \multirow{2}{*}{$\begin{array}{c}\text { Rabbit } \\
\text { (63 to } 91 \mathrm{~d})\end{array}$} \\
\hline & $\begin{array}{c}\text { Starter } \\
(1-14 d)\end{array}$ & $\begin{array}{c}\text { Grower } \\
(15-28 d)\end{array}$ & $\begin{array}{l}\text { Finisher } \\
(29-35 d)\end{array}$ & & \\
\hline Yellow corn & 56.00 & 59.70 & 66.00 & 54.75 & 12.00 \\
\hline Barley grains & - & - & - & - & 10.20 \\
\hline Soybean meal (44\%) & 28.80 & 26.00 & 17.20 & 36.00 & 19.50 \\
\hline Corn gluten meal $60 \%$ & 9.00 & 7.20 & 9.35 & 5.90 & - \\
\hline Wheat bran & - & - & - & - & 29.05 \\
\hline Clover hay & - & - & - & - & 24.50 \\
\hline Soybean oil & 1.50 & 2.80 & 2.85 & 0.45 & - \\
\hline Molasses & - & - & - & - & 2 \\
\hline Limestone & 1.60 & 1.45 & 1.50 & 1.40 & 1.10 \\
\hline Mono Ca Ph. & 1.85 & 1.65 & 1.65 & 0.70 & 0.75 \\
\hline L -Lysine & 0.37 & 0.32 & 0.52 & 0.10 & - \\
\hline DL - Methionine & 0.28 & 0.28 & 0.33 & 0.10 & 0.15 \\
\hline Salt $(\mathrm{NaCl})$ & 0.30 & 0.30 & 0.30 & 0.25 & 0.50 \\
\hline Premix B & 0.30 & 0.30 & 0.30 & - & - \\
\hline Premix Q & - & - & - & 0.30 & - \\
\hline Premix R & - & - & - & - & 0.30 \\
\hline Total & 100 & 100 & 100 & 100 & 100 \\
\hline \multicolumn{6}{|c|}{ Calculated chemical composition } \\
\hline ME Kcal / Kg & 3000 & 3100 & 3200 & 2900 & - \\
\hline DE kcal/ kg\# & - & - & - & - & 2678 \\
\hline Crude Protein $(\%)$ & 23.00 & 21.00 & 19.00 & 24.01 & 16.87 \\
\hline Crude fiber $\%$ & 3.57 & 3.42 & 2.96 & 4.01 & 12.94 \\
\hline Calcium (\%) & 1.00 & 0.91 & 0.91 & 0.80 & 0.84 \\
\hline Available Phosphorus (\%) & 0.51 & 0.46 & 0.45 & 0.30 & 0.40 \\
\hline Methionine (\%) & 0.66 & 0.62 & 0.65 & 0.50 & 0.41 \\
\hline Meth. + Cyst. (\%) & 1.05 & 0.98 & 0.98 & 0.77 & 0.63 \\
\hline Lysine (\%) & 1.40 & 1.62 & 1.25 & 1.30 & 1.03 \\
\hline
\end{tabular}

Premix B: Composition of vitamin and minerals premix. Each $3 \mathrm{~kg}$ of vitamin and mineral mixture contains : $12000000 \mathrm{IU}$ vitamin A; $2000000 \mathrm{IU}$ Vit. D3; $10 \mathrm{~g}$ Vit. E; $1 \mathrm{~g}$ Vit. K; $1 \mathrm{~g}$ B1; $5 \mathrm{~g}$ Vit. B2; 1500 mg B6; $10 \mathrm{mg}$ Vit. B12; $10 \mathrm{~g}$ Pantothenic Acid ; $20 \mathrm{~g}$ Nicotenic Acid; $1 \mathrm{~g}$ Folic Acid; $50 \mathrm{mg}$ Biotin; $500 \mathrm{~g}$ Choline Chloride ; $4 \mathrm{~g}$ Copper; $300 \mathrm{mg}$ Iodine ; $30 \mathrm{~g}$ Iron; $60 \mathrm{~g}$ Manganese; $50 \mathrm{~g}$ Zinc and $100 \mathrm{mg}$ Selenium.

Premix Q: Each $3 \mathrm{~kg}$ of vitamins and minerals premix contains: $12000.000 \mathrm{IU}$ vitamin A acetate; 2000.000 IU vitamin D3.; $10.000 \mathrm{mg}$ vitamin E acetate; $2000 \mathrm{mg}$ vitamin $\mathrm{K3} ; 100 \mathrm{mg}$ vitamin B1; 4000 $\mathrm{mg}$ vitamin B2; $1500 \mathrm{mg} \mathrm{B6;10} \mathrm{mg} \mathrm{vitamin} \mathrm{B12;} 10.000 \mathrm{mg}$ pantothenic acid; $20.000 \mathrm{mg}$ Nicotinic acid; $1000 \mathrm{mg}$ Folic acid; $50 \mathrm{mg}$ Biotin; $500.000 \mathrm{mg}$ chorine; $10.000 \mathrm{mg}$ copper; $1000 \mathrm{mg}$ Iodine; $300.00 \mathrm{mg}$ Iron; $55.000 \mathrm{mg}$ Manganese; $55.000 \mathrm{mg}$ Zinc, $100 \mathrm{mg}$ Selenium.

Premix R: Each $3 \mathrm{~kg}$ of premix contains Vit. A 12000000 IU; Vit. D, 2000000 IU; Vit. E 10000 mg; Vit. $K_{3} 2000 \mathrm{mg}$; Vit. B $1000 \mathrm{mg}$; Vit. $B_{2} 5000 \mathrm{mg}$; Vit. $B_{6} 1500 \mathrm{mg}$; Vit. $B_{12} 10 \mathrm{mg}$; Biotin $50 \mathrm{mg}$; Coline Chloride $250000 \mathrm{mg}$; Pantothenic acid $10000 \mathrm{mg}$; Nicotinic acid $30000 \mathrm{mg}$; Folic acid $1000 \mathrm{mg}$; Manganese 60000 mg; Zinc 50000 mg; Iron 30000 mg; Copper 10000 mg; Iodine 1000 mg; Selenium $100 \mathrm{mg}$; Cobalt $100 \mathrm{mg}$

. \# Digestible energy (DE) was calculated according to Fekete and Gippert (1986) by applying the equation DE $(\mathrm{kcal} / \mathrm{kg})=4253-32.6($ CF \%) -144.4 (total ash \%).

In Exp. (2), the three levels of AgNPs were offered to 90 one-day old broiler chicks (Ross 500) through 35 days trial period as chicks were randomly distributed into 3 treatments where 30 chicks were allocated for each level. Chicks were kept in one 2 sided battery contained 3 stairs with 5 cages each and 3 birds kept in each cage which was $50 * 50 * 45 \mathrm{~cm}$, length, width and hight dimensions, respectively. Briefly; 1 battery $* 2$ sided $* 3$ stairs $* 5$ cages $* 3$ chicks $=90$ chicks, and each treatment contained 30 chicks). Diets were formulated according to NRC (1994) and chicks fed on diets which described in Table (1) by metallic feeders with ad libitum system and chicks subjected to $24 \mathrm{~h}$ light at first 3 days and $22 \mathrm{~h}$ light $+2 \mathrm{~h}$ dark daily program from 4 till 35 days of age. 


\section{El-Faham et al.}

In Exp. (3), 45 one-day old chicks of Japanese quail were randomly distributed on floor pens supported with plastic waters and feeders from 1 till 7 days of aga; then kept in specific battery from 7 to 42 days of age with automatic nipples and metallic feeders. Fifteen one-day old chicks were allocated each treatment (0,5 and $10 \mathrm{ppm} \mathrm{AgNPs} \mathrm{/} \mathrm{liter} \mathrm{drinking} \mathrm{water)} \mathrm{till} 42$ days old. Chicks received $22 \mathrm{~h}$ daily light through experimental period, and kept in $36{ }^{\circ} \mathrm{C} 1-14$ days of age then gradually decreased by $2{ }^{\circ} \mathrm{C}$ each week till $25^{\circ} \mathrm{C}$ which was fixed till the end of experimental period. House temperature and ventilation was controlled by electric fans and thermostatic heaters. Chicks were offered one type of diet as described in Table (1) with ad libitum system along experimental period and drinking water was freely supplied through the experimental period.

The nano-silver was brought from the Nano-technology Unit, Faculty of Science, South Valley, Qena University, Egypt. The Nanotechnology Center contributed to this the research by supplying AgNPs free of charge.

\section{Measurements:}

\section{Body weight and feed efficiency:}

Exp. (1), rabbits of each treatment were individually weighed at the beginning and at the end of trial to determine weight gain then divided in 28 to get daily weight gain by grams. The remainder of feed was subtracted from feed offered at beginning of each week and then divided by 7 to calculate daily feed intake, weekly.

Exp. (2), for each treatment; body weight was measured every 2 weeks of experimental period starting from one day old, accordingly, body weight gain (BWG) from 1 to 42day old, was calculated g / day. Also, feed intake (FI) was calculated every 2 wks at 2, 4, 6 and overall period g / day. Feed conversion ratio (FCR) was calculated by dividing FI by BWG corresponding.

Exp. (3), chicks of Japanese quail and their feed intake were weighed every 3 weeks, consequently body weight gain and feed intake were calculated and then feed conversion ratio was calculated by dividing FI/BWG values at 0-3 wks and 3-6 wks every 3 wks periods.

\section{Carcass characteristic:}

Exp. (1): At the end of experiment, 6 fasting rabbits from each treatment were, weighed then sacrificed till complete bleeding, then hot carcass was weighed. Heart, liver and kidneys were removed and weighed. Dressing percentage (including head, liver and heart) was calculated as a percent of pre-slaughtered live body weight, while heart, liver and kidneys were calculated as a percent of live body weight.

Exp. (2): At the trial ended, Six broiler chicks from each treatment were chosen, weighed then slaughtered tell complete bleeding. Afterwards, hot carcass was weighed and liver, gizzard and heart were removed and weighed. Hot carcass and all mentioned organs were calculated as a percent of pre- slaughtered live body weight.

Exp. (3): At the end of experiment five chicks of Japanese quail at the end of experiment from each treatment were randomly selected and fasted for $12 \mathrm{~h}$., then slaughtered to complete bleeding. Defeathered carcass was weighed, head and feet. Also, dressed carcass, liver, heart and gizzard, were calculated as a percent of live body weight.

Bacterial counts of small intestine segments: After slaughtering of selected rabbits, broilers chick and Japanese quail chicks, the content of the three segments of small intestine for each treatment group, were taken separately and evacuated in weighed screw-capped sterile plastic cups then well mixed. The sealed containers were kept on ice until they were transported to the laboratory (MERCEN) for enumeration of microbial population. The fresh mass was mixed with appropriate volume of sterile $0.1 \%$ peptone solution to prepare $1: 10$ dilution. Ten fold serial dilutions up to $10^{7}$ of each sample were then prepared in $9 \mathrm{ml}$ of $0.1 \%$ sterile peptone solution. Viable counts bacteria; E. Coli and Lactobacilli were performed using the spreadplate technique. Total bacteria count were enumerated on nutrient agar (Oxoid), incubated aerobically at $37^{\circ} \mathrm{C}$. The Eosin methylene blue (EMB) agar (Oxoid) was used for E. coli, incubated aerobically at $37^{\circ} \mathrm{C}$. Plates were counted between 24 and $48 \mathrm{~h}$ after incubation. For lactobacilli, deMan, Rogosa and Sharpe (MRS) agar (Biolife) was used, and the plates were incubated in $5 \% \mathrm{CO} 2$ for $48 \mathrm{~h}$. The media plates were inoculated with $0.1 \mathrm{ml}$ of the sample dilutions. Three dilutions were plated for each count as appropriate (101, 103 and 105 for E. 
coli and 103, 105 and 107 for total aerobes and lactobacilli). After incubation, colonies were counted according to colony morphology for E. coli (isolated colonies with dark purple centers and greenish metallic sheen) and lactobacilli (small opaque and white, compact or feathery colonies). For total aerobes all colonies were counted. Counts from two plates were averaged. Numbers of colony-forming units (CFU) are expressed as log colony-forming units per gram of digesta content.

Statistical analysis: for the three experiments, data of species, carcass traits and microbial counts (CFU $\log / \mathrm{g}$ ) were statistically analyzed using SAS software (2004) with one way analysis of variance procedure, and differences between means were separated using Duncan's multiple range test (1955) at significance level 0.05 . The statistical model was performed as follow:

$$
Y_{i j}=\mu+T_{i}+E_{i j},
$$

Where: $Y_{i j}=$ the experimental observation, $\mu=$ overall mean, $T_{i}=$ the effect of $i^{\text {th }}$ dietary treatment and $\mathrm{E}_{\mathrm{ij}}=$ random error.

\section{RESULTS AND DISCUSSION}

\section{Productive performance:}

EXP. (1):There is no significant effect ofl of AgNPs level in drinking water on body weight, body weight gain or feed conversion ratio of rabbits along experimental grower period (Table 2). Rabbits with access to drinking water supplemented with $10 \mathrm{ppm}$ reflected the lowest body weight, body weight gain and worst feed conversion ratio compared with other treatments. However, daily feed consumption was significantly reduced at $10 \mathrm{ppm}$ level; whereas rabbits offered control or 5 ppm AgNPs consumed higher feed than 10 ppm group.

EXP. (2): Results presented in Table (2) revealed that AgNPs supplementation in drinking water of broiler chicks from one day to 35 days reduced body weight gain and feed intake $(\mathrm{p}<0.05)$, whereas control group gained more weight $(2007 \mathrm{~g})$ and consumed more feed $(3970 \mathrm{~g})$ than those chicks received water contained 5 ppm and 10 ppm AgNPs. Moreover, although, feed conversion ratio, didn't significantly differ between treatments, but 5 ppm group get best value of feed efficiency (1.86) which may be attributed to the lower feed intake more than body weight gain value.

EXP. (3): It is clear from Table (2) that, for most grower stages, body weight and body weight gains of grower quail were not significantly affected by AgNPs supplementation in drinking water. Chicks received $10 \mathrm{ppm}$ AgNPs in water significantly consumed lower feed through all growing periods compared with control or $5 \mathrm{ppm}$ groups. The corresponding figures were 538.5 versus 601.6 and $588.6 \mathrm{~g}$; respectively with significant differences between treatments. Although chicks received $10 \mathrm{ppm}$ AgNPs, significantly proved the best significant feed efficiency value through all periods, the control group actually performed the worst feed efficiency due to its lower BWG and higher feed intake than 5 and $10 \mathrm{ppm}$ groups, and the corresponding figures being $3.39,3.17$ and 2.97 , respectively.

\section{Carcass characteristics:}

Exp. (1): Data included in Table (3) indicated that different levels of AgNPs in drinking water didn't significantly affect any percentage of dressing or carcass characteristics of experimental rabbits at 91d old. In general, the worst carcass characteristics were recorded when 10 ppm AgNPs was incorporated in water.

Exp. (2): Supplementation of drinking water through the 35 days growing period didn't significantly affect most carcass characteristics of broiler chicks (Table 3 ). The corresponding values for dressing \% ranged between 65.01 and $69.71 \%$, while ready to cook $\%$ ranged between 73.12 and $73.88 \%$, without any significant differences.

Exp. ((3): Data presented in Table (3) showed that different levels of AgNPs in drinking water didn't significantly affect percent of slaughter parts of grower quails except for liver percent which recorded a higher value for $5 \mathrm{ppm}$ group (2.53\%) compared with control $(1.86 \%)$ and $10 \mathrm{ppm}(1.89 \%)$ treatments. 
Table (2): Effect of different AgNPs levels in drinking water on productive performance of broiler chicks, Japanese quail and growing rabbits .

\begin{tabular}{|c|c|c|c|}
\hline Item & Broiler chicks & Japanese quail & Growing rabbits \\
\hline Live body weight (g) & $(1-35 d)$ & $(7-42 d)$ & (63-91d) \\
\hline Control & $2046.2^{\mathrm{a}}$ & 215.0 & 1708.2 \\
\hline $5 \mathrm{ppm}$ & $1817.8^{\mathrm{c}}$ & 222.8 & 1685.2 \\
\hline $10 \mathrm{ppm}$ & $1881.1^{\mathrm{b}}$ & 219.0 & 1581.0 \\
\hline Sig. \# & $*$ & NS & NS \\
\hline \multicolumn{4}{|l|}{ Body weight gain (g) } \\
\hline Control & $2007.0^{\mathrm{a}}$ & 177.5 & 531.2 \\
\hline $5 \mathrm{ppm}$ & $1780.0^{\mathrm{c}}$ & 185.5 & 508.2 \\
\hline $10 \mathrm{ppm}$ & $1843.0^{\mathrm{b}}$ & 181.5 & 404.0 \\
\hline Sig.\# & * & NS & NS \\
\hline \multicolumn{4}{|l|}{ Total feed intake (g) } \\
\hline Control & $3970.0^{\mathrm{a}}$ & $601.6^{\mathrm{a}}$ & $2232.2^{\mathrm{a}}$ \\
\hline $5 \mathrm{ppm}$ & $3581.0^{\mathrm{c}}$ & $588.6^{\mathrm{a}}$ & $2333.2^{\mathrm{a}}$ \\
\hline $10 \mathrm{ppm}$ & $3627.0^{\mathrm{b}}$ & $538.5^{\mathrm{b}}$ & $1949.9^{\mathrm{b}}$ \\
\hline Sig. \# & $* *$ & $* *$ & $*$ \\
\hline \multicolumn{4}{|l|}{$\begin{array}{l}\text { Feed conversion ratio } \\
\text { (g feed/g gain) }\end{array}$} \\
\hline Control & 1.97 & $3.39^{\mathrm{a}}$ & 4.21 \\
\hline $5 \mathrm{ppm}$ & 1.86 & $3.17^{\mathrm{a}}$ & 4.59 \\
\hline $10 \mathrm{ppm}$ & 1.96 & $2.97^{\mathrm{b}}$ & 4.84 \\
\hline Sig. \# & NS & $* *$ & NS \\
\hline
\end{tabular}

\section{Intestinal bacterial counts:}

Exp. (1): Increasing of AgNPs level in drinking water of growing rabbits significantly $(\mathrm{p}<0.05)$ and linearly reduced counts of total viable bacteria and E coli but insignificantly increased Lactobacilli count of intestinal gut (Table 4).

Exp. (2): Counts of total viable bacteria, Lactobacillus and $\mathrm{E}$ Coli in intestinal gut of broiler chicks as marked in Table (4) were significantly suppressed $(\mathrm{P} \leq 0.01)$ with AgNPs incorporation in drinking water with a linear trend compared with control chicks.

Exp. (3): Results presented in Table (4) indicate a significant linear reduction in counts of total bacteria, Lactobacillus and E Coli of intestinal gut for both AgNPs water - supplemented groups of grower quails compared with their control group ( $\mathrm{p} \leq 0.01)$. Also, it is obvious that control and $5 \mathrm{ppm}$ groups didn't significantly differ in Lactobacillus count while the group received $10 \mathrm{ppm}$, recorded a lower count.

It is clear that, there is a difference between both grower rabbits and Japanese quail from one side and grower broiler chicks from the other side for responding to AgNPs incorporation in drinking water. As, the different levels of AgNPs in drinking water hadn't any significant effect on body weight, body weight gain or FCR of rabbits (Table 2); at the same time it tended to negatively affect those parameters in broiler chicks where control group performed well compared with supplemented groups, especially for body weight gain and FCR. Additionally, results of Table (4) showed that $5 \mathrm{ppm}$ and $10 \mathrm{ppm}$ treatment, resulted in a reduction in total viable bacteria, pathogenic bacteria representing E Coli and beneficial bacteria representing Lactobacillus of intestinal gut, especially for $10 \mathrm{ppm}$ level for Japanese quail and broiler chicks.

Concerning inferior body weight gain and feed conversion ratio for rabbits and broiler chicks accompanied with supplemented groups compared with the control group. It might be attributed to the suppressive effect of AgNPs on counts of beneficial and total viable bacteria 
of intestinal tract and prevailing the desired suppressive effect on intestinal E Coli. The situation is more different for the effect on Japanese quail, where AgNPs supplementation in drinking water resulted in significant improvement in body weight gain and feed efficiency only up to $5 \mathrm{ppm}$ level compared with control and $10 \mathrm{ppm}$ groups as showed in

Table (3). Effect of different AgNPs levels in drinking water on carcass characteristics of broiler chicks (35d), Japanese quail (42d) and growing rabbits (91d) of age.

\begin{tabular}{|c|c|c|c|}
\hline $\begin{array}{l}\text { Item } \\
\text { (\%LBW) }\end{array}$ & Broiler chicks & Japanese quail & Growing rabbits \\
\hline \multicolumn{4}{|l|}{ Ready to cook ${ }^{*}$} \\
\hline Control & 73.12 & 70.62 & 62.50 \\
\hline $5 \mathrm{ppm}$ & 73.32 & 71.70 & 62.42 \\
\hline $10 \mathrm{ppm}$ & 73.88 & 72.08 & 62.30 \\
\hline Sig. \# & NS & NS & NS \\
\hline \multicolumn{4}{|c|}{ Dressing percentage } \\
\hline Control & 65.01 & 66.14 & 57.41 \\
\hline $5 \mathrm{ppm}$ & 68.60 & 66.52 & 57.51 \\
\hline $10 \mathrm{ppm}$ & 69.71 & 67.56 & 57.04 \\
\hline \multirow{2}{*}{\multicolumn{4}{|c|}{$\begin{array}{l}\text { Sig. } \\
\text { Liver }\end{array}$}} \\
\hline & & & \\
\hline Control & 2.45 & $1.86^{\mathrm{b}}$ & 2.98 \\
\hline $5 \mathrm{ppm}$ & 2.34 & $2.53^{\mathrm{a}}$ & 2.91 \\
\hline $10 \mathrm{ppm}$ & 2.15 & $1.89^{\mathrm{b}}$ & 3.05 \\
\hline Sig. \# & NS & $* *$ & NS \\
\hline \multicolumn{4}{|l|}{ Gizzard } \\
\hline Control & 1.43 & 1.93 & -- \\
\hline $5 \mathrm{ppm}$ & 1.49 & 1.95 & -- \\
\hline $10 \mathrm{ppm}$ & 1.44 & 1.90 & -- \\
\hline Sig."\# & NS & NS & -- \\
\hline \multicolumn{4}{|l|}{ Heart } \\
\hline Control & 0.55 & 0.69 & 0.24 \\
\hline $5 \mathrm{ppm}$ & 0.54 & 0.70 & 0.28 \\
\hline $10 \mathrm{ppm}$ & 0.57 & 0.73 & 0.31 \\
\hline Sig.\# & NS & NS & NS \\
\hline \multicolumn{4}{|l|}{ Kidneys } \\
\hline Control & -- & -- & 0.67 \\
\hline $5 \mathrm{ppm}$ & -- & -- & 0.74 \\
\hline $10 \mathrm{ppm}$ & -- & -- & 0.78 \\
\hline Sig. \# & -- & -- & NS \\
\hline
\end{tabular}

Table (1), which might be attributed to strict reduction in E. Coli count accompanied to AgNPs supplementation in drinking water while Lactobacillus count didn't significantly differed between control and 5 ppm groups. Our results concerning grower rabbits and broiler chicks are in contrast to those reported by Hassanabadi et al. (2012), Marwa et al. (2012) and Kout Elkloup et al. (2015). However; they agree in regard to Japanese quail, where their studies stated a beneficial and positive effect of AgNPs supplementation in drinking water or diet on body weight gain and feed efficiency of laying quail and broiler chicks. And, they attributed these findings to the reduction in pathogenic bacteria and significant increment of beneficial bacteria for supplemented groups causing improvement in nutrient utilization and body weight gain. Supporting to our results about grower rabbits and broiler chicks, Burrell et al. (1999), indicated that AgNPs is considered as a potential killing agent for broad spectrum of gram positive and gram negative bacteria. This finding is more obvious for both experimental species causing a negative effect on body weight and feed efficiency. While lactobacillus bacteria tended to decline with supplemented group, grower quails may be less sensitive for this effect than rabbits and broiler chicks where growth rate and feed efficiency positively 
affected till 5 ppm level. Hence, according to concerned study, it is suggested that AgNPs with tested levels in drinking water showed antibacterial effects for both common pathogenic (negative gram) bacteria and beneficial (positive gram) bacteria of intestinal gut of tested poultry species causing negative effect on performance of grower rabbits and broiler chicks. Both species may be more sensitive for existence of AgNPs in drinking water.

Table (4). Effect of different AgNPs levels in drinking water on some microbial counts of small intestine of broiler chicks (35d), Japanese quail (42d) and growing rabbits (91d) of age.

\begin{tabular}{|c|c|c|c|}
\hline Item & Broiler chicks & Japanese quail & Growing rabbits \\
\hline \multicolumn{4}{|l|}{ Total Viable Count } \\
\hline Control & $18.3 \times 10^{6 \mathrm{a}}$ & $263.33 \times 10^{5 \mathrm{a}}$ & $7.69 \times 10^{4 \mathrm{a}}$ \\
\hline $5 \mathrm{ppm}$ & $56.3 \times 10^{5 b}$ & $77.33 \times 10^{5 b}$ & $7.86 \times 10^{4 a}$ \\
\hline $10 \mathrm{ppm}$ & $9 \times 10^{4 c}$ & $4.43 \times 10^{5 c}$ & $6.50 \times 10^{4 \mathrm{~b}}$ \\
\hline Sig. & $* *$ & $* *$ & * \\
\hline \multicolumn{4}{|l|}{ E. Coli Count } \\
\hline Control & $64.3 \times 10^{5 \mathrm{a}}$ & $4966.3 \times 10^{4 \mathrm{a}}$ & $3.32 \times 10^{4 a}$ \\
\hline $5 \mathrm{ppm}$ & $9.0 \times 10^{5 b}$ & $2733.3 \times 10^{4 b}$ & $3.29 \times 10^{4 \mathrm{~b}}$ \\
\hline $10 \mathrm{ppm}$ & $11.7 \times 10^{4 \mathrm{c}}$ & $7.7 \times 10^{4 \mathrm{c}}$ & $2.92 \times 10^{4 \mathrm{c}}$ \\
\hline Sig. & $* *$ & $* *$ & $*$ \\
\hline \multicolumn{4}{|l|}{ Lactobacillus Count } \\
\hline Control & $20.7 \times 10^{5 \mathrm{a}}$ & $16.67 \times 10^{5 \mathrm{a}}$ & $4.22 \times 10^{4}$ \\
\hline $5 \mathrm{ppm}$ & $80.7 \times 10^{4 b}$ & $18.33 \times 10^{5 \mathrm{a}}$ & $4.71 \times 10^{4}$ \\
\hline $10 \mathrm{ppm}$ & $7.3 \times 10^{4 \mathrm{c}}$ & $3.37 \times 10^{5 \mathrm{c}}$ & $4.39 \times 10^{4}$ \\
\hline Sig. & $* *$ & $* *$ & $\mathrm{NS}$ \\
\hline
\end{tabular}

The non-significant effect of drinking water AgNPs supplementation on most carcass characteristics (except abdominal fat in broiler chicks and liver percent of grower quail) in the three species is in agreement with Ahmed and Rahimi (2011), Felehgari et al. (2013) and Kout Elkloup et al. (2015), While, the higher abdominal fat associated with AgNPs treatment in broiler , disagrees with Ahmed and Rahimi (2011) who reported a significant increase in abdominal fat weight with all broiler groups fed different dietary levels of AgNPs compared to control chicks. As well as, liver percent significantly increased in quail chicks till $5 \mathrm{ppm}$ AgNPs level compared with control or $10 \mathrm{ppm}$ groups, this result is somewheat disagree with that reported with Andi et al. (2011) whose showed a negative effect of different levels of AgNPs on relative weight of liver compared to control group. The higher abdominal fat associated with AgNPs supplementation in broiler chicks and the significant increment in liver percent of grower Japanese quails till 5ppm AgNPs level, requires more investigation.

\section{CONCLUSION}

The use of nano-silver in drinking water at $10 \mathrm{ppm}$ improved the FCR of Japanese quail while it had a negative effect on broiler chicks and had no effect on growing rabbits, And,it also had a clear effect on total number of bacteria and E.Coli of intestinal media.

\section{REFERENCES}


Ahmadi, F. and A.H. Kurdestany, 2010. The impact of silver nano particles on growth performance, lymphoid organs and oxidative stress indicators in broiler chicks. Global Veterinaria, 5: 366-370.

Ahmadi, F. and F. Rahimi, 2011. The effect of different levels of nano silver on performance and retention of silver in edible tissues of broilers. World Applied Sci. J., 12: 1-4.

Ahmadi, J., 2009. Application of different levels of silver nanoparticles in food on the performance and some blood parameters of broiler chickens. World Applied Sci. J., 7: 24-27.

Andi, M.A., M. Hashemi and F. Ahmadi, 2011. Effects of feed type with/without nanosil on cumulative performance, relative organ weight and some blood parameters of broilers. Global Veterinaria, 7: 605-609.

Burrell, R.E., J.P. Heggers, G.J. Davis and J.B. Wright, 1999. Efficacy of silver-coated dressings as bacterial barriers in a rodent burn sepsis model. Wounds, 11: 64-71.

Duncan, D. B.,1955. Multiple range and multiple F test. Biometrics 11: 1-42.

Felehgari, K., F. Ahmadi, A. Rokhzadi, A.H. Kurdestany and M.M. Khah, 2013. The effect of dietary silver nanoparticles and inorganic selenium supplementation on performance and digestive organs of broilers during starter period. Bull. Environ. Pharmacol.LifeSci.,2:104-108.

Grodzik, M., E. Sawosz, 2006: The influence of silver nano-particles on chick embryo development and bursa fabri-cius morphology. J. Anim. Feed Sci.15 Supl. 1, 111-115.

Hang, D.T. and T.T.T. Tra (2013). Effect on rabbit reproduction of adding silver-nano suspension to the drinking water. Livestock Research for Rural Development. Volume 25, Article \#162.

Hassanabadi, A.I., H.I. Hajati and L. Bahreini, 2012. The effect of nanosilver on performance carcass characteristics, immune system and intestinal microfelora of broiler chickens. Proceedings of the 3rd International Veterinary Poultry Congress, February 22-23, 2012, Tehran, Iran .

Hong, J.S., S. Kim, S.H. Lee, E. Jo and B. Lee, 2014. Combined repeated-dose toxicity study of silver nanoparticles with the reproduction/developmental toxicity screening test. Nanotoxicology, 8: 349362.

Kout Elkloub, M. El. Moustafa, A.A. Ghazalah and A.A.A. Rehan, 2015. Effect of Dietary Nanosilver on Broiler Performance. International Journal of Poultry Science, 14: 177-182.

Lepianka, A., J.L. Sok?, 2006: Effect of nanoparticles of noble metals on growth and development of chosen bacteria in poultry intestine, in vitro. (in Polish) Proceed-ings from 3rd Conference of Young Scientists, Warsaw, 21.-22.10.06, Kielanowski Institute of Animal Physiology and Nutrition and Warsaw Agricultural University Warszawa, 41.

Marwa, Sh. Abdo. (2012). Effect of some physiological and environmental factors on reproductive activity of laying quail. Faculty of Agriculture, Ain Shams University. Egypt, PP:108-112.

NRC "National Research Council" (1994): Nutrient Requirements of Poultry. 9th. Rev. (Edn.). National Academy Press, Washington, DC.,USA.

Pineda Lane, Chwalibog A, Sawosz Ewa, Lauridsen Charlotte,Engberg R, Elnif J, Hotowy Anna, Sawosz F, Yuhong Gao, Abdalla Ali and Heshmat Sepehri Moghaddam 2012: Effect of silver nanoparticles on growth performance, metabolism and microbial profile of broiler chickens, Archives of Animal Nutrition, 66:5, 416-429.

SAS., 2004. SAS procedure Guide, Version 6.12 th. SAS Institute, Cary, NC., USA.

Sawosz, E., M. Binek, M. Grodzik, M. Zielinska and P. Sysa et al., 2007. Influence of hydrocolloidal silver nanoparticles on gastrointestinal micro-flora and morphology of enterocytes of quails. Arch. Anim. Nutr., 61: 444-451.

WHO (World Health Organization). Report of a joint FAO/OIE/WHO Expert Consultation on Antimicrobial Use in Aquaculture and Antimicrobial Resistance. Seoul, Republic of Korea, 13 - 16 June 2006. 
تأثير إضافة جزيئات النانو سليفر في ماء الثرب على ألاداء والمجتمع البكتيري لأمعاء الدواجن النامية

أحمد ابر اهيم القحام و مراد حامد السنهورى و كحم مصطفي السيد مصطفي

قسم انتاج الدواجن - كلية النزراعة - جامعة عين شمس

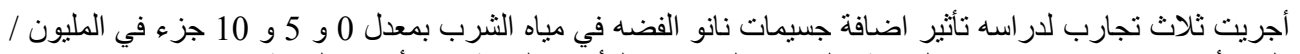

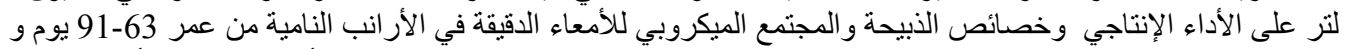

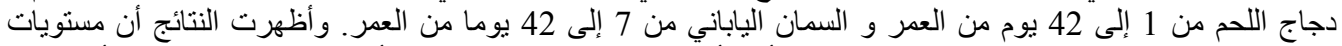

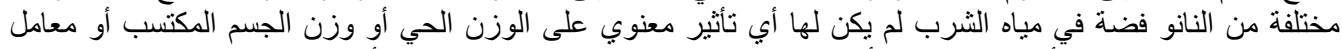

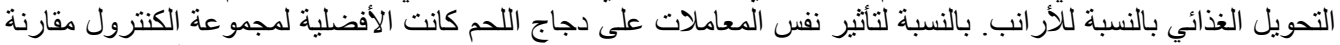

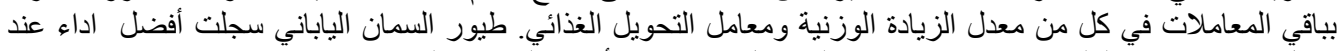

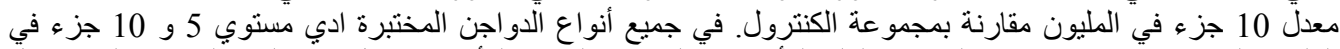

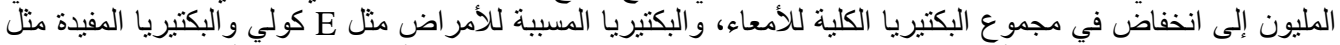

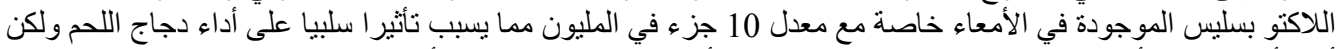

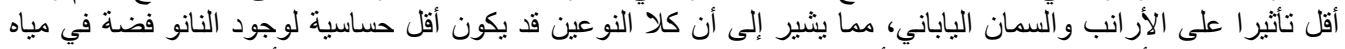

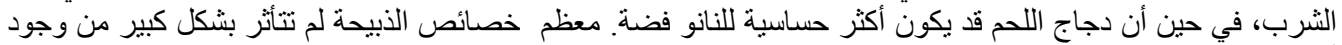

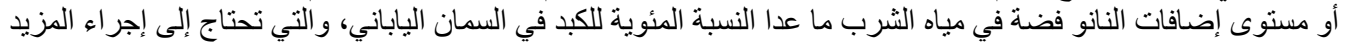

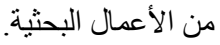

